Article

\title{
Supply Chain Finance in China: Business Innovation and Theory Development
}

\section{Xiaohong Liu ${ }^{1}$, Liguo Zhou ${ }^{1}$ and Yen-Chun Jim Wu ${ }^{2, *}$}

1 Business School, Central University of Finance and Economics, Beijing 100081, China; E-Mails: xliu@cufe.edu.cn (X.L.); prozlg@163.com (L.Z.)

2 Graduate Institute of Global Business and Strategy, National Taiwan Normal University, Taipei 106, Taiwan; E-Mail: wuyenchun@gmail.com

* Author to whom correspondence should be addressed; E-Mail: wuyenchun@gmail.com; Tel.: +886-2-7734-3996; Fax: +886-2-2364-8372.

Academic Editor: Giuseppe Ioppolo

Received: 7 July 2015 / Accepted: 26 October 2015 / Published: 3 November 2015

\begin{abstract}
Supply chain finance (SCF) is concerned with the capital flows within a supply chain, an area often neglected in past decades, while SCF does have an impact on a firm's capability to adopt sustainable supply chain management (SCM) practices. The aim of this study is to explore new insight from a growing body of research which is investigating SCF issues in China, an evolving transition economy. A content analysis on a review of 151 Chinese-written SCF papers from 2004-2014, based on a sample of 45 leading Chinese journals (Chinese Social Science Citation Index, CSSCI) was conducted from three perspectives: topical coverage, theoretical application and methodological inquiry. The study reveals that the research stream of SCF in China has emerged and evolved to a considerable extent. However, the SCF phenomenon in China is not exactly the same as "SCF" as it is perceived in the mature economy, which is articulated in mainstream SCM English literature. The Chinese business context in which SCF has been implemented has played a dominant role in initiating, affecting and even shaping SCF. This study represents the first endeavor in the field of SCM. It diffuses the Chinese-written SCF research in mainstream SCM English literature.
\end{abstract}

Keywords: supply chain finance; supply chain management; business innovation; China 


\section{Introduction}

In China, the difficulty experienced by small and middle enterprises (SMEs) in obtaining bank loans has been a longstanding issue. The reason behind this problem is complicated. It is generally recognized that SMEs suffer from a shortage of fixed assets, limited capacity of credit rating and an under-developed SMEs' credit guarantee system in China [1,2]. The emergence of a supply chain finance (SCF) solution in recent years has, however, improved the situation. By pledging their movable assets, such as raw materials and consumer products, to banks as security, SMEs are able to borrow funds from banks from which they could not borrow in the conventional loaning system.

By nature, SCF is a business model concerned with the capital flow within a supply chain, an area neglected often in past supply chain management (SCM) practices. According to Gomm [3], optimizing the financial structure and the cash-flow within the supply chain can be identified with SCF. More specifically, Pfohl and Gomm [4] defined SCF as "the inter-company optimization of financing as well as the integration of financing processes with customers, suppliers, and service providers in order to increase the value of all participating companies" (p. 151). The objective of SCF, as Gomm [3] noted, is to decrease the cost of capital and speed up cash-flow by optimizing financing across company borders.

The application of the SCF approach in business is significant. First, SCF implementation is able to alleviate the pressure of working capital encountered by SMEs, accordingly relieving the capital-constrained supply chain as a result of these SME members having capital constrained in the supply chain. Second, the resultant SMEs financing demand arising from SCF has led banks to a derivative deposit and enormous intermediate business income, hence a new profit point of growth. Moreover, as released by relevant bank reports in China, there are no-performing loans (NPLs) recorded by the top banks in China for their engaged SCF business. Third, the collateral under control of banks is looked after by a logistics service provider (LSP), which is designated by banks. LSPs have therefore gained advantage, by providing value-added services for SMEs with service compensation for conducting inventories and managing on one hand, and value appraising and monitoring banks on the other. Thus, by leveraging the SCF model, the affiliated partners in the SCF solution, i.e., SMEs, banks and LSPs, can obtain triple wins through close coordination and cooperation. Given its significance, SCF has been highly regarded as an innovation in the business world. The "Chief Finance Officer", a business magazine in China, has stated in its 2012 China Supply Chain Financing Demand Report that more and more SMEs which had been unable to pass the rating auditing and obtain credit support in terms of their financial statements have now turned to the SCF approach. Likewise, CI Consulting, a leading professional institution in the field of industry research in China, also reported that the scale of financing by SCF in 2011 was 5.75 billion Yuan, increasing to 6.9 billion Yuan with a growth rate of $20 \%$.

The potential that the SCF initiative exerts to SCM has, however, intrigued Chinese scholars. So far, there has been clear academic recognition of the need for the SCF initiative in China. SCF has become one of the most intensely studied topics in Chinese SCM research. China is the largest transitional economy in the world. Currently, it is experiencing dual transition from a planned economy and traditional agricultural society to a market-oriented economy and industrial society after over 30 years of reform and opening up. This unique context, as noted by many scholars [5-8], presents new research questions to academic research. Given an identified practical value of SCF out of this specific setting, 
and a topic which has prompted much discussion amongst Chinese academics, we are interested in finding answers to the following questions: what is the body of knowledge concerning SCF in China? To what extent is SCF in China contingent on a specialized business environment? What implications can we draw from SCF research in China? Unfortunately, given that the issue of SCF is heavily under-researched in mainstream SCM literature, the dissemination of SCF in China is, nevertheless, lacking. The present study is intended to fill the void.

To address these research inquiries explicitly, we initiate an investigation which is built upon the Chinese SCF papers. Admittedly, the research on SCF in the SCM field is rare and, thus, no data from the extant literature can afford such discussion. Yet, the information from Chinese scholarship can provide us with an insider's perspective to observe this development, which is particularly appropriate for the present study. Given the language difference, while considerable SCM research has been reported in the Chinese language in recent years, little in this field has been accessed from outside. The present study will close this gap as well.

The paper proceeds as follows: The following section describes the content analysis-based methodology employed in the study. Next, the research findings are presented in terms of topical coverage, theoretical application and methodological inquiry. These sections are followed by detailed discussions and implications. Finally, the conclusion is presented.

\section{Research Methodology}

The purpose of this present study is to explore new insight in respect to an emerging SCF research phenomenon in China, a transitional economy. To this end, a Chinese-based literature review of SCF was surveyed. The content analysis was utilized to develop a profile of these Chinese SCF papers.

Content analysis is "a research technique for the objective, systematic and quantitative description of the manifest content of communication" [9]. The goal of content analysis is "to identify and record relatively objective (or at least intersubjective) characteristics of messages" [10]. Content analysis can combine qualitative approaches retaining rich meaning with powerful quantitative analyses, where it seems meaningful for the analyst [11]. The content analysis approach has been applied by many SCM researchers when studying journal articles $[12,13]$. To identify more influential works on SCF research in China, we processed a content analysis consisting of four steps: journal selection, article identification, category classification and subject evaluation.

\subsection{Journal Selection}

As there is no consensus on the journals specific to SCM typology in China, the papers published on SCM are scattered. In consideration of the influence of the papers in China, we therefore went to the database of the CSSCI (Chinese Social Science Citation Index), which is widely acknowledged in the Chinese academic community. Given that SCF is a product of integrating logistics services and finance services $[3,4,14]$, two categories, namely management and economics, were considered. Accordingly, 102 journals, including 29 management journals and 73 economics journals, were targeted. As CSSCI is recognized amongst Chinese academics as being a list of top-tier journals, the results should have strong explanatory power. 


\subsection{Article Identification}

Consequently, a search of relevant papers from the literature of management and economics was conducted. The process of article searching included two stages. In the first stage, we reviewed the title and abstract of each article based upon a series of keywords, such as "supply chain finance/financing", "logistics finance", "warehouse receipt" and "inventory financing". After careful screening and evaluation of all the articles published in the 102 journals during the period of 2004-2014, 155 papers were selected. In the second stage, we reviewed the full texts of these articles. Four papers, two being the literature review and the other two being irrelevant to the theme discussed, were therefore excluded. In the end, 151 fully refereed papers in 45 journals were selected for study. In principle, these identified papers met the general requirements in accordance with articles published in refereed English journals (Table 1).

Table 1. Papers distributed by top-tier Chinese journals.

\begin{tabular}{clc}
\hline No. & Chinese Journal & Number (\%) \\
\hline 1 & Systems Engineering & $13(8.6 \%)$ \\
2 & Soft Science & $10(6.6 \%)$ \\
3 & Journal of Management Sciences in China & $9(6.0 \%)$ \\
4 & Systems Engineering-Theory \& Practice & $9(6.0 \%)$ \\
5 & East China Economic Management & $8(5.3 \%)$ \\
6 & Chinese Journal of Management Science & $7(4.6 \%)$ \\
7 & Journal of Industrial Engineering and Engineering Management & $7(4.6 \%)$ \\
8 & Management Review & $7(4.6 \%)$ \\
9 & Journal of Central University of Finance and Economics & $5(3.3 \%)$ \\
10 & Finance Forum & $4(2.6 \%)$ \\
11 & Forecasting & $4(2.6 \%)$ \\
12 & Journal of Shanxi Finance and Economics University & $4(2.6 \%)$ \\
13 & Research on Financial and Economic Issues & $4(2.6 \%)$ \\
14 & Shanghai Finance & $4(2.6 \%)$ \\
15 & The Theory and Practice of Finance and Economics & $4(2.6 \%)$ \\
16 & Economic Theory and Business Management & $3(2.0 \%)$ \\
17 & Economic Review & $3(2.0 \%)$ \\
18 & Economic Survey & $3(2.0 \%)$ \\
19 & Economic Management Journal & $3(2.0 \%)$ \\
20 & Economist & $3(2.0 \%)$ \\
21 & Inquiry into Economic Issues & $3(2.0 \%)$ \\
22 & Journal of Business Economics & $3(2.0 \%)$ \\
23 & Journal of Financial Research & $3(2.0 \%)$ \\
24 & Research on Economics and Management & $3(2.0 \%)$ \\
25 & Chinese Soft Science Magazine & $2(1.3 \%)$ \\
26 & Nankai Business Review & $2(1.3 \%)$ \\
27 & Science \& Technology Progress and Policy & $2(1.3 \%)$ \\
28 & Collected Issues on Finance and Economics & $1(0.7 \%)$ \\
29 & Contemporary Finance \& Economics & $1(0.7 \%)$ \\
30 & Economic Perspectives & $1(0.7 \%)$ \\
\hline & &
\end{tabular}


Table 1. Cont.

\begin{tabular}{clc}
\hline No. & Chinese Journal & Number (\%) \\
\hline 31 & Economic Review by Wuhan University & $1(0.7 \%)$ \\
32 & Economic Science & $1(0.7 \%)$ \\
33 & Finance \& Economics & $1(0.7 \%)$ \\
34 & Finance \& Trade Economics & $1(0.7 \%)$ \\
35 & Finance and Trade Research & $1(0.7 \%)$ \\
36 & International Business & $1(0.7 \%)$ \\
37 & Issues in Agricultural Economy & $1(0.7 \%)$ \\
38 & Journal of Management Sciences & $1(0.7 \%)$ \\
39 & Journal of System \& Management & $1(0.7 \%)$ \\
40 & Macroeconomics & $1(0.7 \%)$ \\
41 & Modernization of Management & $1(0.7 \%)$ \\
42 & Price: Theory \& Practice & $1(0.7 \%)$ \\
43 & Reform of Economic System & $1(0.7 \%)$ \\
44 & Science Research Management & $1(0.7 \%)$ \\
45 & Shanghai Economic Review & $1(0.7 \%)$ \\
In total & & 151 \\
\hline
\end{tabular}

Figure 1 presents the sample distributed by year. The results show that the year 2011 yielded most publications, with 27 papers accounting for $17.9 \%$. In addition, the number of the publications shows an increasing tendency during the period 2004-2011. To some extent, the results suggest that SCF has received more and more attention in the past decade.

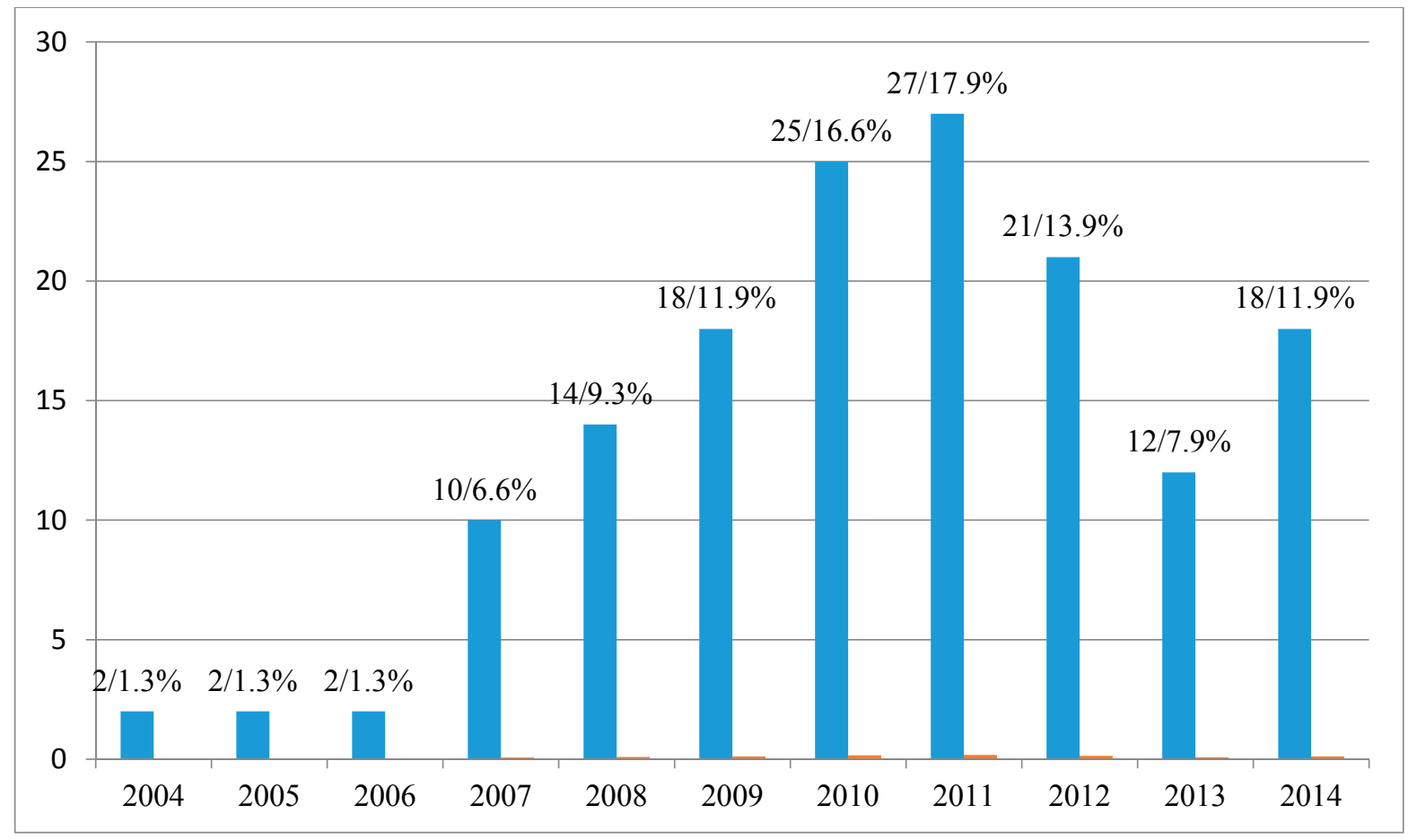

Figure 1. Papers distributed by year. 


\subsection{Category Classification}

The papers identified were classified according to analytical units. In this study, three main analytical categories were taken into account: topical coverage, theoretical application and methodological inquiry. Each main category was further divided into sub-units for analysis. For example, in the category of topical coverage, more subject matters were identified as the sub-units to be assessed.

\subsection{Subject Evaluation}

The sample was analyzed according to the categories predefined. The results were presented, discussed and interpreted, with the aim of revealing findings and further providing implications for future study.

\section{Review Findings}

In China, SCF is regarded as a collaborative entity consisting of multiple organizations. Primarily, it is composed of three participants: borrowing companies, commercial banks and LSPs. Borrowing companies are normally recognized as some SMEs which need funds to function and expand their business. As a result of the lack of insufficient fixed assets, these SMEs leave their liquid assets as a security or collateral to banks. This is nevertheless different from traditional commercial loans which rely on fixed assets as security. Commercial banks are referred to those institutions which accept deposits, make business loans and offer basic investment products. Given the unavailability of fixed assets from SMEs, it is a last-ditch move for commercial banks to secure loans in terms of movable assets. Commercial banks determine the financing with its mode, duration and cost. Given the policy restriction, commercial banks are not allowed to engage in non-financial business. Therefore, LSPs are entrusted by commercial banks responsible for monitoring the assets and providing other relative services. Three different organizations collaborate and coordinate on the monetization of collateral. Figure 2 schematizes a typical model of SCF in China.

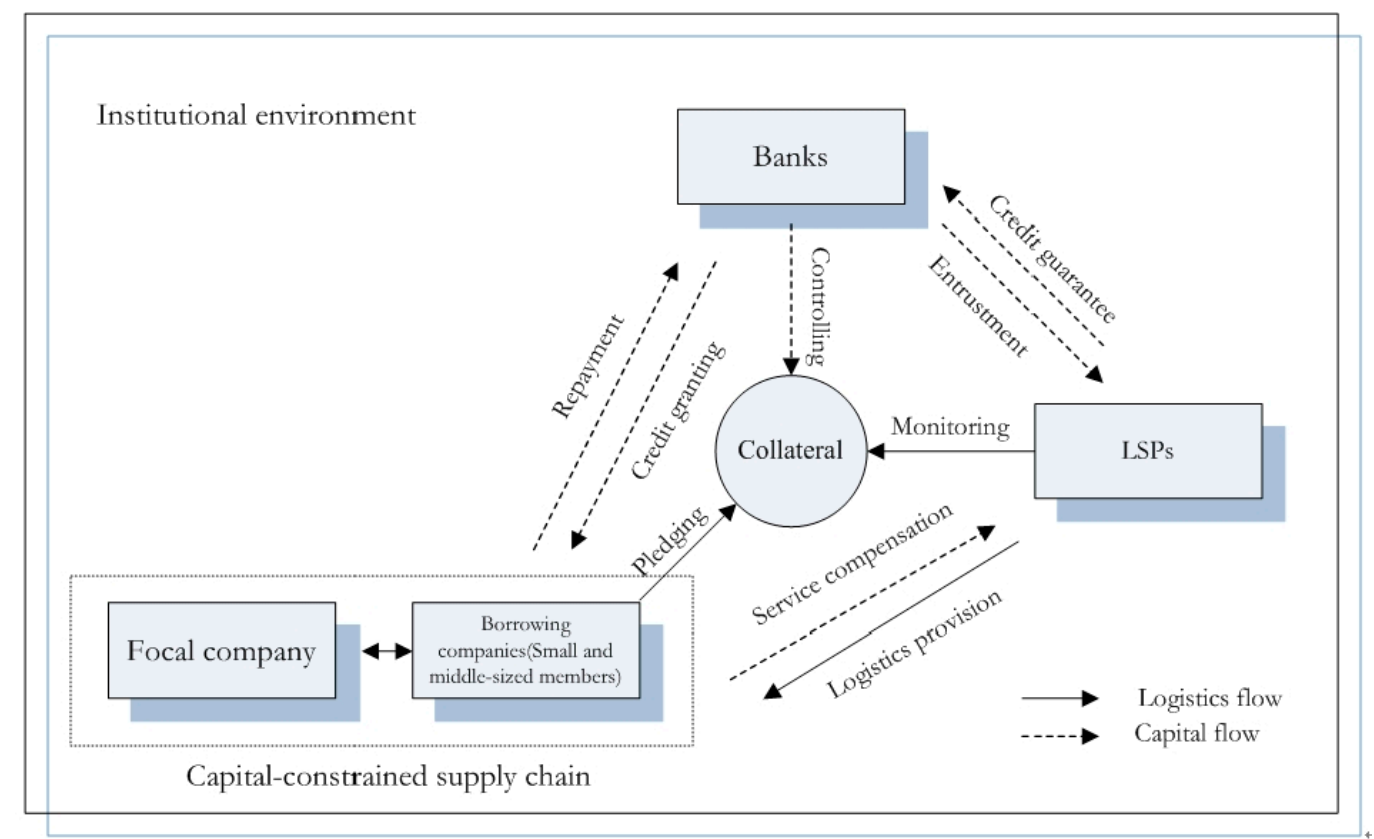

Figure 2. A typical model of supply chain finance in China. 


\subsection{Topical Coverage}

From the category of topical coverage, we found that the papers reviewed fall into five principal groups: concept development, operation and coordination of affiliated partners, risk management, collateral and the SCF environment in China. Table 2 shows the topical coverage.

Table 2. Topical coverage of Chinese-written SCF research.

\begin{tabular}{|c|c|c|c|c|}
\hline No. & Topical Coverage & Count (\%) & Sub-Unit & Count $(\%)$ \\
\hline \multirow{2}{*}{1} & \multirow{2}{*}{ Concept development } & \multirow{2}{*}{$44(29.1 \%)$} & Drivers & $29(19.2 \%)$ \\
\hline & & & Innovative characters & $15(9.9 \%)$ \\
\hline \multirow{9}{*}{2} & \multirow{9}{*}{$\begin{array}{l}\text { Operation and coordination } \\
\text { of involved parties }\end{array}$} & \multirow{9}{*}{$61(40.4 \%)$} & Decision & $26(17.2 \%)$ \\
\hline & & & Benefit sharing & $12(7.9 \%)$ \\
\hline & & & Incentive & $8(5.3 \%)$ \\
\hline & & & Coordination & $5(3.3 \%)$ \\
\hline & & & Credit & $4(2.6 \%)$ \\
\hline & & & Operation capacity & $3(2.0 \%)$ \\
\hline & & & Network governance & $1(0.7 \%)$ \\
\hline & & & Outsourcing and value-added services & $1(0.7 \%)$ \\
\hline & & & Technology & $1(0.7 \%)$ \\
\hline \multirow{5}{*}{3} & \multirow{5}{*}{ Risk management } & \multirow{5}{*}{$45(29.8 \%)$} & Risk control & $19(12.6 \%)$ \\
\hline & & & Risk assessment & $10(6.6 \%)$ \\
\hline & & & Risk measurement & $6(4.0 \%)$ \\
\hline & & & Risk prevention & $6(4.0 \%)$ \\
\hline & & & Risk identification & $4(4.0 \%)$ \\
\hline 4 & Collateral management & $4(2.6 \%)$ & type and value variation & $4(2.6 \%)$ \\
\hline 5 & Institutional environment & $1(0.7 \%)$ & Law institution & $1(0.7 \%)$ \\
\hline
\end{tabular}

Note: Some papers were assigned more than one category.

\subsubsection{Concept Development}

In total, 44 (29.1\%) papers conceptualize the emergence and development of the SCF phenomenon in China. The subject matters of these papers are concerned mainly with the drivers and innovative characteristics of SCF. The primary driver of the SCF initiative, as indicated previously, is commonly recognized as the difficulty of loaning for SMEs. Given insufficient assets and credit, it is difficult for SMEs to borrow funds secured by fixed or credit-based financing. In addition, from a supply chain perspective, $\mathrm{Hu}$ and Huang [15] explained that the increasing globalization and outsourcing trend has led to fewer assets for the members in the supply chain. Then, SCF, as an innovative financing solution, bridges the bank and capital-constrained SME members in the supply chain and creates value for the supply chain with capital constraints. With regard to innovative characters differing from a conventional financing model targeted at individual companies, SCF is recognized by Chinese scholars, such as Xu and Xia [16], as an effective approach for solving chain-based SME financing. The discussion also confirms Hofmann's [14] statement that SCF is a network of companies collaborating across traditional 
financial boundaries. In general, the discussions in respect to the emergence and development of SCF in China provide a basis for exploring the field in the Chinese context.

\subsubsection{Operation and Coordination of Involved Parties}

SCF is a collaborative entity primarily encompassing three participants: borrowers, banks and LSPs, as indicated previously. These three parties have their own industrial characteristics. The successful SCF implementation is contingent on better cooperation and collaboration in the same language between these partners. Moreover, since more than two participants may be involved, benefit arrangement and sharing among multiple sides becomes an issue. Sixty-one (40.4\%) papers contained a discussion on this issue from different angles, i.e., one party, dyadic relations and the supply chain. For example, from an LSP's point of view, Chen and Zhu [17] indicated the value system of LSPs to the supply chain with capital constraints, as addressed by Hofmann [18]. From the perspective of dyadic relations, He et al. [19] investigated the game behavior of banks and LSPs in inventory financing by means of the Stackelberg model, suggesting that, with complete information, the advantage gained from a joint decision made by both banks and LSPs is greater than that of the decision made by banks only. From a supply chain perspective, Bai et al. [20] analyzed the levels of effort and the relationship between a borrowing company and its collaborative partners by establishing an incoming model concerning all partners in the SCF.

Specifically, the subject matter with respect to the operation and coordination of involved parties is concentrated on decision-making, benefit sharing, incentives, coordination, credit, outsourcing and value-added services, operation capabilities, technology and network governance. For example, Ma and Zhu [21] highlighted the importance of the monitoring decision made by an LSP in inventory financing. Drawing on principal-agent theory, $\mathrm{Xu}$ et al. [22] discussed the incentive and supervision mechanisms established by banks for LSPs in inventory financing. By applying game theory, Wen and Ye [23] indicated the theoretical benefit of sharing between borrowing companies and banks. In general, the discussions include not only the cooperation and collaboration among collaborative parties in the implementation process, i.e., outsourcing and value adding, operational capabilities, coordination, but also behavior, i.e., incentive. These discussions respond to the assertion made by Johnson and Hofmann [24] that SCF is an approach which coordinates the joint activities of participants, requiring integration across both business functions and organizations in order to facilitate the capital conversion cycle.

\subsubsection{Risk Management}

Risk management is a key to the accomplishment of SCF. It entails managing risks that can endanger the SCF performance. In the SCF context, risk management can be viewed from three aspects. First, SCF deals with the capital management against liquid assets by integrating financial services and logistics services. How to avoid risks incurred by banking transaction and logistics operations is crucial to SCF implementation. Second, SCF in China is aimed at SMEs. Owing to a series of factors, such as lower credit rating, high default frequency and inadequate credit guarantee system, the credit of SMEs is a major problem in China. This, however, gives rise to credit risk. Third, as an innovative business model, SCF requires cooperation and collaboration between multiple participating companies with different characteristics. Under this circumstance, as the exposure profile of risks has been shifted from a single organization to the members within a "chain", the principle of supply chain risk management 
(SCRM), as stated by many authors [25-27], is applied. On one hand, the structure of SCF makes the participants more vulnerable to the traditional risks encountered by a single organization. On the other hand, the structural characteristics of SCF can allow the partners to join forces to reduce such risks; for example, the role LSPs play in addressing the asymmetric flow of information between banks and borrowers, as explicated by Hofmann [18].

In total, 45 (29.8\%) papers highlight risk management arising from SCF, as Table 2 shows. The results reveal that the risks discussed in these studies are involved in all three aspects described above. More specifically, five facets of this, including risk identification, risk prevention, risk measurement, risk control and risk evaluation, were highly relevant.

For instance, drawing on financial system engineering, Li [28] proposed a conceptual framework concerning the identification of the risk sources. He divided these into two categories: system risks (SC, macro-economy and industry) and non-system risks (credit, liquidity and operation). Lv [29] claimed that, when LSPs are engaged in financing businesses, human, financial and material resources should be taken into consideration for risk prevention. Through a sensitivity analysis, Chen et al. [30] discovered that loan-to-value ratios are more sensitive than interest rates when valuing risk in inventory financing. This, nevertheless, comes from the price risk and liquidity risk of the collateral. Given the inadequate credit system in China, Bai [31] placed emphasis on the credit risk. To this end, Bai made an assessment of the credit risk of borrowing companies in SCF by adopting AHP and FCE methods. Han and Li [32] investigated liquidity risk by adopting the L-VaR technique, and proposed the optimal liquidation time model and liquidation strategy. These discussions confirm the suggestion made by some scholars $[3,5]$ that risk management is an important component in the SCF solution.

\subsubsection{Collateral}

The SCF places emphasis on capital flow in a supply chain. However, the capital flow is subject to the collateral on its type, amount and duration, as well as cost of capital rate $[3,4]$. In addition, the variation of the financed goods can also result in risks. Three papers explore the issue of collateral. For example, Bai [33] investigated financing by employing intellectual property as collateral. Xiong et al. [34] discussed the risk phenomenon which is caused by the unstable nature of collateral. Chang et al. [35] proposed that the advantage and disadvantage of the property of movable assets can be judged by measuring the liquidity risk of inventory financing.

\subsubsection{SCF Environment in China}

Of the papers reviewed, many claim a need to improve the business environment in which the SCF is implemented, although no extensive discussions were offered. Nevertheless, one paper placed particular concern on the legal environment that SMEs are subject to in using liquid assets to borrow funds. $\mathrm{Wu}$ [36] found that, since the introduction of property legislation in 2007, movable assets can be treated as either pledge or mortgage. As a result of an inadequate legal system, this could lead to many security rights being tied with the same movable assets, resulting in banks losing property rights. The author, therefore, suggests that it is imperative to strengthen the risk control, improve the judicial interpretation of property law and establish a registration and inquiry system for movable assets. This research finding 
confirms the suggestion by Lacroix and Varangis [37] that a recognized basis in law is necessary for effectively ensuring warehouse receipts in developing countries.

\subsection{Theoretical Applications}

The results reveal that $62(41.1 \%)$ papers applied theoretical perspectives to explain the various phenomena in SCF, as shown in Table 3.

Table 3. Theoretical applications of Chinese-written SCF research.

\begin{tabular}{|c|c|c|}
\hline Theoretical Perspective & Application & Count $(\%)$ \\
\hline Mathematical model & $\begin{array}{l}\text { Copula-GARCH model; DEA-TOPSIS-Malmquist; fuzzy theory; GARCH } \\
\text { model; grey system theory; newsvendor; shapley; SVM; BP; VaR }\end{array}$ & $19(12.6 \%)$ \\
\hline Game & cooperative game; signal game; repeated game; Stackelberg game & $16(10.6 \%)$ \\
\hline $\begin{array}{l}\text { Finance (Bank, Investment, } \\
\text { Accounting, Credit) }\end{array}$ & $\begin{array}{l}\text { capital market; cash to cash flow sensitivity; commercial credit; credit } \\
\text { metrics model; cost-benefit analysis; Danny Ben-shahar mortgage model; } \\
\text { financial systems engineering; hedging; investment-cash flow sensitivity; } \\
\text { non-arbitrage equilibrium; working capital management }\end{array}$ & $12(7.9 \%)$ \\
\hline Economics & $\begin{array}{l}\text { Principal-agent; contract model; transaction cost; the double } \\
\text { auction model }\end{array}$ & $10(6.6 \%)$ \\
\hline Risk & $\begin{array}{l}\text { "corporate and debt" method; Markowitz Portfolio theory; risk } \\
\text { measurement model; structural mutation and liquidity risk model }\end{array}$ & $4(2.6 \%)$ \\
\hline Behavioral science & $\begin{array}{l}\text { incentive theory; incentive-compatibility; relationship; relational } \\
\text { behavior; trust }\end{array}$ & $4(2.6 \%)$ \\
\hline System, Cybernetics & optimal control theory; systematic; system engineering; systems science & $3(2.0 \%)$ \\
\hline Computer & cloud technology & $1(0.7 \%)$ \\
\hline Philosophy & dialectical method & $1(0.7 \%)$ \\
\hline Soft science & soft science & $1(0.7 \%)$ \\
\hline Strategic management & value chain & $1(0.7 \%)$ \\
\hline Symbiosis & symbiosis theory & $1(0.7 \%)$ \\
\hline
\end{tabular}

Note: Some papers use more than one theoretical perspective.

Specifically, the theories regarding mathematics, game theory, economics and finance were utilized more widely. Game theory was used to explain the benefit obtained and reward sharing. For example, He et al. [19] analyzed the game behavior of multi-participants in inventory financing in the case of imperfect information, and found that reward is more effective than punishment in such cases. $\mathrm{Xu}$ et al. [38] discussed the ordering strategy of SCF under the condition of stochastic demands by means of the news vendor model. Drawing on the principal-agent theory, Wang and $\mathrm{Xu}$ [39] discussed the incentives of banks to act as LSPs in view of the factor of justice preference. As SCF is an integrated business model combined with financial services and logistics services, financial theory was used to explain the issues of SCF. For instance, based on the non-arbitrage method, Zhao and Liu [40] proposed an optimized pricing method for LSPs which provide services for SMEs in inventory financing. Drawing upon the Markowitz portfolio theory, He et al. [41] investigated price risk decision-making of inventory portfolios in SCF. In addition, risk, system and behavioral sciences and other disciplines are applied, like those in the SCM research. 
The application of multiple discipline theories indicates that SCF is a complicated phenomenon, requiring different theories to explain it. On the other hand, the application of theories may define the nature and scope of SCF research.

\subsection{Methodological Inquiry into SCF in China}

From a methodological viewpoint, the papers reviewed were divided into three categories: conceptual proposition, empirical analysis and mathematical modeling, as presented in Table 4.

Table 4. Methodological inquiry of Chinese-written SCF research.

\begin{tabular}{|c|c|c|c|c|}
\hline Methodological Perspective & Count (\%) & & Count (\%) & Analytical Technique \\
\hline Conceptual proposition & $54(35.8 \%)$ & & & Description and interpretation \\
\hline \multirow{4}{*}{ Empirical analysis } & \multirow{4}{*}{$26(17.2 \%)$} & Survey & $6(4.0 \%)$ & \multirow{3}{*}{ Statistical/Econometric } \\
\hline & & Questionnaire & $9(6.0 \%)$ & \\
\hline & & Desk data & $1(0.7 \%)$ & \\
\hline & & Case study & $10(6.6 \%)$ & $\begin{array}{c}\text { Interpretation (qualitative) } \\
\text { Statistical/Econometric (quantitative) }\end{array}$ \\
\hline Mathematical modeling & $72(47.7 \%)$ & & & Mathematical modeling design \\
\hline
\end{tabular}

Note: Some articles use more than one method.

As presented in Table 4, mathematical modeling and conceptual proposition hold two large groups, whereas empirical research represents only a small part. Mathematical modeling tends to solve the problems in SCF by employing mathematical concepts and languages. For example, Han and Li [32] proposed a measurement model for risk control in the inventory financing by adopting the method of liquidity-adjusted value at risk ( $\mathrm{L}-\mathrm{VaR})$. The conceptual proposition is intended to develop, formulate and clarify specific concepts pertinent to SCF; for example, Hu and Wang [15] conceptualized the SCF with its background, innovative characteristics and concept delimitation. Empirical research tests the hypotheses by focusing on real situations. With regard to empirical study, for instance, from the perspective of supply chain finance, $\mathrm{Hu}$ et al. [42] empirically examined the influence of supply chain partnerships on SMEs' working capital building upon questionnaire data. In addition to the questionnaire, the survey and case study provided empirical evidence for the SCF research.

In general, researchers applied more attention to the conceptual description or theoretical discussion by means of mathematical testing, rather than empirical verification, in particular, theory building. This might suggest that the SCF research in China is in its early stages, although a certain amount of the research has been established. This finding responds to the suggestions by Pofhl and Gomm [4] that more evidence from practice is necessary to explore the value of SCF implementation. In addition, the SCF research in China presents many policy implications. This confirms the survey of Chinese literature on the management of technology and innovation conducted by White et al. [8]. The likely explanation, as White et al. [8] concluded, is that policymakers have a need for research that would help them design, implement, and evaluate both macroeconomic and microeconomic policies which define the transition period. 


\section{Discussions and Implications}

According to the latest research report on SCF conducted by Demica, the growth prospect of SCF in the world is promising. It is expected that annual SCF growth rates will rise between $10 \%$ and $30 \%$ per annum in mature markets, and $20 \%$ and $25 \%$ in emerging markets. The need for financing in the developing economies, such as China and India, is particularly pressing to help deal with rapid expansion. Indeed, as a transitional economy with institutional and structural shortcomings, China needs new market instruments to ensure its economic progress. The emergence of SCF, however, represents such an initiative, as it can ease the SMEs' financing, a problem deeply rooted in its institutions. This encourages Chinese scholars to explore further the research potential in this area.

With this trend in mind, we believe there is immense opportunity for further SCF research in China. Aligning with the research findings revealed, we ascertain that there are three particular concerns: the research potential of SCF in China, different foci of SCF research in China, and the rigor and relevance of SCF research in China.

\subsection{Research Potential of SCF in China}

Johnson and Hofmann [24] stated that SCF requires an integration of process and organization. At the process level, SCF is concerned with the coordination of capital and logistics within a SCM under the support of standardized IT and a favorable institutional environment. At the organizational level, SCF demands closer coordination between finance, SCM, and outside cooperation, operational and financial operation. In this respect, there should be a variety of topics for exploration and development, as called for by Johnson and Hofmann [24].

Given the topical coverage presented in the analysis, i.e., concept development, operation and coordination of involved parties, risk management, collateral and the institutional environment of SCF in China, some missing topics require critical attention, as exemplified with the following two themes: integration of material, information and financial flows, and performance measurement of SCF.

\subsubsection{Integration of Material Flows, Information Flows and Financial Flows}

A prerequisite for successful SCM is the integration of all the business processes within a supply chain. Traditionally, material flows and information flows are identified as being two distinct flows within a supply chain. The integration of the two flows is therefore identified as a key aspect of SCM. Zsidisin et al. [43] considered the primary goal of SCM as "effectively managing the flow of materials and information from supply sources to the final point of sale" (p. 312). Stevens [44] elaborated the potential of integrating material flows and information flows with reference to the manufacturing industry. Moshkdanian and Molahosseini [45] empirically investigated the integration of both information and material flows among supply chain partners and its effect on operational performance.

The emerging SCF research has asserted the importance of the financial flows within SCM, which was largely ignored previously. The performance of the SCM, as Mentzer et al. [46] stated, rests on the synergies of multiflows, including products/materials, information and finances along the supply chain. By employing a case-based approach, Randall and Farris II [47] demonstrated that supply chain financial management techniques can improve supply chain profitability and performance. Given this 
recognition, no longer can the potential of integrating the materials flows, information flows and financial flows be disregarded. This raises a series of questions concerning the integration of multiflows in a supply chain. Do the financial flows hinder the integration of the supply chain, and if so, why? In the SCF context, how can the financial flows integrate with the material flows and information flows? What is the effect of the integration of the financial flows with the other flows (i.e., materials and information)? How can SCF performance reap benefit from the integration of the three flows?

\subsubsection{Performance Measurement of SCF}

The SCF initiative is an integrated product of logistics services and financial services. Given different concerns, the two types of services are measured differently. Logistics services are concentrated on cost reduction, time saving and service quality optimization, while financial services are focused on capital constraint and asset quality. The measurement of logistics performance is assumed to be a difficult and complex endeavour, and no single paradigm can be used. Mentzer and Konrad [48] reviewed logistics performance practices and suggested methods for improvement from an efficiency/effectiveness perspective. The focus of this approach is on the extent to which goals are achieved (effectiveness) and resources utilized (efficiency). Caplice and Sheffi [49,50] indicated that the logistics performance measurement could be measured using either individual metrics or at system-wide levels.

Compared with logistics services, the measurement system of financial services seems to be very explicit, given the maturity of the bank industry. Indicators such as interest rates, capital ratio, credit growth rates, non-performing loans (NPLs) and NPL ratio are generally used. In such cases, how might the performance of SCF be assessed? Which metrics could be applied for the measurement of SCF performance? In addition, SCF is highly coherent with fundamental tenets of SCM [47]. A "chain"-wide performance involves more elements and measures as well [51,52]. In this sense, which principles of SCM might be considered in developing the measurement metrics for SCF performance?

\subsection{Different Foci of SCF Research in China}

From the studies by Chinese scholars on SCF, we found an interesting phenomenon. The SCF phenomenon in China is not exactly the same as the "SCF" perceived in mature markets, which is articulated in the leading English literature. Table 5 presents such differences.

Table 5. A comparison of SCF as perceived in China and by mature markets.

\begin{tabular}{|c|c|c|c|}
\hline Differences & $\begin{array}{l}\text { Mature Markets } \\
\text { (by SCM English Literature) }\end{array}$ & China (by the Present Study) & Major Reason for SCF in China \\
\hline Primary driver & $\begin{array}{l}\text { Working capital optimization and } \\
\text { reduction of supply chain risk have } \\
\text { been identified as the driving forces } \\
\text { for the establishment of the SCF } \\
\text { programs }[4,14,47]\end{array}$ & $\begin{array}{l}\text { SMEs unable to access to liquidity } \\
\text { through conventional banking loans } \\
\text { and therefore the resultant impact } \\
\text { on the supply chain operation is the } \\
\text { key motivation }\end{array}$ & $\begin{array}{l}\text { Prescribed economic system and } \\
\text { financial institution; immature } \\
\text { market mechanism }\end{array}$ \\
\hline Type of collateral & $\begin{array}{l}\text { Both movable and unmovable } \\
\text { assets }[3,4,14]\end{array}$ & Movable assets & Immature market mechanism \\
\hline Role of LSPs & $\begin{array}{l}\text { Traditional logistics services; agency } \\
\text { services; financial services }[18,53,54]\end{array}$ & $\begin{array}{l}\text { Traditional logistics services; } \\
\text { agency services }\end{array}$ & Mixed operation is banned \\
\hline
\end{tabular}


The financing problem of SMEs in China is predominant, as noted at the outset. The difficulties are attributed to the serious financing constraints faced by SMEs [1,2]. On a deeper level, this originates from economic systems and financial institutions. For example, according to the current financial policies, corporate ownership is one of the main factors considered by banks when deciding whether to give a loan. Under this circumstance, state-owned enterprises (SOEs) with a strong reputation can enjoy more preferential benefits from the policy [55,56]. On the contrary, SMEs are off limits, given their scale. This is, however, termed as "ownership discrimination".

In addition, according to current policies, mixed operation in the financial sector is banned in China, although it is recognized as an inevitable trend for the Chinese financial industry to develop towards mixed operation policy. Therefore, non-financial organizations are not allowed to access financial business. This is the so-called "separated operation model". In line with this policy, the role played by Chinese LSPs in SCF is limited to two facets only: traditional logistics services and delegate services entrusted by banks. They cannot play the role of their counterparts in the market economy, namely, an integrator for both an LSP and a bank. Likewise, banks cannot offer logistics services to borrowing companies. This is distinct from that of a market economy, in which more logistics companies, such as DHL and UPS, offer financing as part of their supply-chain services, as indicated by some studies $[18,53,54]$, or vice versa. This difference identified by the present study is, however, reflective of national characteristics in implementing SCF.

Tsui [7] claimed that the contextual background would have an influence on business management. Specifically, with a particular reference to China, Child [57] emphasized the nation's context whereby government, business systems and intermediate institutions have particular relevance for business. Based on an empirical study, Avittathur and Swamidass [58] found that the supply chain environment in developing nations like India, China and Thailand may not be similar to the environment in developed countries, resulting in different operations and management.

Our finding nonetheless offers further evidence to these studies. On one hand, our study reveals that the SCF phenomenon is contingent on specific national or business system characteristics. On the other hand, given these different perceptions arising from a different market system, SCF scholars should be very aware of the influence of contextual background on the SCF phenomenon and implementation. More important, the institutional environment of SCF in China should be highly valued.

An institutional environment is concerned with the various institutional factors underlying a nation. By empirically conducting a study concerning the institutional environment in Japan, Thailand and China, Yaibuathet et al. [59] revealed that the institutional environment could be one of the main obstacles in improving the operational performance of a supply chain. Given the specifics of China in the SCM field, there is an increasing emphasis on the Chinese institutional environment to better understand the SCM practice. For example, Qing and Cong [60] identified some institutional factors, such as the Chinese economic institution, the managerial mode, the social credit system and the undeveloped logistics infrastructure base, etc. Huo et al. [61] examined the impact of the three aspects of institutional pressures - normative, mimetic and coercive-on supplier integration and financial performance. From an institutional point of view and in terms of the specific environment of China, Su et al. [62] empirically examined the SCM of Chinese firms, suggesting that three aspects - the economic institutions of China and the world, the history and cultural environment of China, and organization and management institutions of Chinese firms - should be paid particular attention. 
As with the studies noted above, a series of inquiries regarding the institutional environment of SCF in China can also be proposed. For example, to what extent does the institutional environment in China substantially influence the adoption and implementation of SCF? What are the typical institutional factors related to the adoption of SCF? How do they exert their influence?

\subsection{Rigor and Relevance of SCF Research in China}

Partly as a result of the novelty and complexity of the SCF phenomenon in China, the SCF research tends to be conceptual and modeling-orientated, as revealed by analysis. For the former, these conceptual works are descriptive and prescriptive. To a large extent, these papers introduce concepts and discuss the implications for policymakers. The prescriptions presented seem intuitively reasonable, yet they do not have any support from empirical evidence and hypothesis-testing methodologies, as White et al. [8] observed. An extensive discussion of empirical data and its analysis is, however, missing. This to some extent reflects the notion that the particular characteristics of the transitional economy are influencing the Chinese-written SCF research field, as noted in the foregoing analysis.

For the latter, most studies utilize mathematical modeling and the construction of mathematical formulae, a description of a system using mathematical language thinking. Indeed, a large quantity of mathematical modeling can predicate and help to validate some phenomena, theoretically building upon mathematical analysis, but mathematical models are not reality. The real world is often far more complex than the mathematical models used to simulate it [63]. It has its limitations, in particular, in practice-generated research, such as SCF.

$\mathrm{SCF}$ is derived from practice initiated by logistics and financial practitioners. Without problems occurring in real SCF, there would be no need for SCF research. From this starting point, to advance and mature SCF research in China, an appropriate methodology with rigor and relevance should be developed. Essentially, relevance should mean that the knowledge generated is valid, meaningful and useful, i.e., relevant for the SCF in the Chinese context. The Chinese researchers should choose topics that are relevant to Chinese SCF practice and is also important and interesting in the Chinese context. Rigor requires that there is validity in the SCF research in China in terms of measurement, sampling, data quality and research design.

Tsui [7] advocated contextualization research in China in consideration of the unique Chinese characteristics in management and organizational behavior. Her advice is very relevant to SCF research in China. Taking the SCF environment in China as an example, specifically, three forms could be conceived in order to ensure the rigor and relevance of SCF research in China.

(1) Main effects. This considers the impact of national attributes on SCF, with the use of national attributes as independent variables (predictors) and SCF as a dependent variable. For example, the research question could be: to what extent is SCF in China a result of the national business environment?

(2) Moderator. This considers a national attribute as a moderator which may change the relationship between independent variables and the dependent variable in the SCF context. For example, in the SCF implementation, LSPs are mostly SOEs, a term which cannot be found in the market economy system. Hence, a likely inquiry could be: to what extent might ownership impact on an LSP's performance in the SCF context? 
(3) Unique role. This considers the unique SCF environment in China. Given a particular social, cultural and historical context, one might wish to understand the different structure of SCF in China when compared with the SCF model in market economies. How is the SCF environment in China defined? Why is it so special?

With regard to the methodology applied, in the first two forms, as contextual characteristics are the primary explanatory variables, either as the main effects or moderator, the deductive approach drawing on the existing literature or theory can be employed. In the last form, the novel context of SCF in China is never explored; this demands an inductive approach and grounded theory to discover regularities in a new phenomenon. For example, Wuttke et al. [64] utilized an inductive multiple case study approach with six European firms to explore how the innovation adoption of SCF might be managed. As for grounded theory, Eisenhardt [65] noted that it is particularly appropriate for when a phenomenon is poorly defined and when no existing theories can be used to explain such a phenomenon. The application of the grounded theory methodology in the SCM field is also noted, given the complexity of SCM. For example, Manuj and Sahin [66] employed grounded theory methodology to build a theory of the complexity of decision-making in a supply chain. Nevertheless, grounded theory requires skills in generalizing findings from large amounts of quantitative and qualitative data featuring highly contextualized information. Given this case, both Chinese knowledge and conceptual capability are essential for developing Chinese SCF theories and models.

\section{Conclusions}

With the research endeavors made by Chinese scholars, as manifested by the study, a new research stream of SCF in the Chinese academic community has emerged and evolved to a considerable extent.

This research phenomenon is salient. This is not merely the novelty of SCF in the SCM field; it also originates from a quasi-experimental setting, i.e., China's evolving transitional economy. As revealed by the study, the Chinese context has raised a set of research questions relating to SCF, which is, however, different from that found in the market economy, in which "business is as usual". In this study, the influence of the Chinese context on SCF is significant. It has played a predominant role in initiating, affecting and even shaping SCF. On one hand, this reinforces an emerging recognition in the SCM research that research phenomena and findings are relevant to specific national characteristics, as noted in the study. On the other hand, this also suggests that SCF researchers cannot afford to ignore those contextual factors when conducting SCF research. The influence of those contextual factors deserves due recognition and specification.

The value from researching the Chinese-written SCF papers is also far-reaching. It exposes a new area which has never been explored in mainstream SCM research in past decades, although some literature studies have delivered China-based logistics and SCM research by means of English language papers [67-69]. One can, however, be informed by new insights from the indigenous findings characterizing the economic transition. The knowledgeable contribution from local researchers publishing in Chinese outlets has been noted in the general management literature [6-8,70]. Given the international presence of the SCM discipline, the indigenous SCF, or more widely, SCM studies, may also contribute to mainstream SCM research, becoming part of the SCM knowledge base. However, to foster this integration, the rigor and relevance of Chinese-written SCF must be improved; in particular, 
the SCF research needs more empirical investigation with managerial implications rather than policymaker implications only.

As the first research endeavor in the SCM literature, the present study cannot avoid its limitations. The goal of our study is to cover Chinese-written SCF papers comprehensively. As evidenced in the study, there is a broad spectrum of SCF dissemination in China. Given source and journal constraints, we were unable to access SCF papers in other non-CSSCI journals. While we have captured the leading outlets of Chinese papers (CSSCI), we might have missed contributions from other outlets concerning $\mathrm{SCF}$ research. We will attempt to map more extensive literature in our future work.

Using the present study as a case in point, we hope that more studies on SCF in China, in more emerging economies, could be diffused widely in the mainstream SCM field. In addition, to make it well-disseminated, we also hope that mutual collaboration between indigenous scholars and international scholars could become possible, sharing a dyadic perspective with both "outsider" and "insider" knowledge on SCF.

\section{Acknowledgments}

This research is being supported by a grant from National Natural Science Foundation of China (No. 71272235) and the Ministry of Education (China) of Humanities and Social Science project (No. 14YJA630034).

\section{Author Contributions}

Xiaohong Liu performed the data analysis and contributed to drafting this manuscript. Liguo Zhou assisted in developing the cencept and design. Yen-Chun Jim $\mathrm{Wu}$ provided useful advice and revised the draft.

\section{Conflicts of Interest}

The authors declare no conflict of interest.

\section{References}

1. Hong, Z.; Zhou, Y. Can third party's collateral arrangements tackle the financing problem of small-medium enterprises? China Financ. Rev. Int. 2013, 3, 353-380.

2. Wu, J.; Song, J.; Zeng, C. An empirical evidence of small business financing in China. Manag. Res. News 2008, 31, 959-975.

3. Gomm, M.L. Supply chain finance: Applying finance theory to supply chain management to enhance finance in supply chains. Int. J. Logist. Res. Appl. 2010, 13, 133-142.

4. Pfohl, H.-C.; Gomm, M. Supply chain finance: Optimizing financial flows in supply chains. Logist. Res. 2009, 1, 149-161.

5. Hofmann, E.; Belin, O. Supply Chain Finance Solutions: Relevance-Propositions-Market Value; Springer: Berlin, Germany, 2011.

6. Peng, M.W.; Lu, Y.; Shenkar, O.; Wang, D.Y.L. Treasures in the china house: A review of management and organizational research on greater China. J. Bus. Res. 2001, 52, 95-110. 
7. Tsui, A.S. Contributing to global management knowledge: A case for high quality indigenous research. Asia Pac. J. Manag. 2004, 21, 491-513.

8. White, S.; Liu, X.; Xie, W. A survey of chinese literature on the management of technology and innovation, 1987-1997. Int. J. Technol. Manag. 2001, 21, 130-150.

9. Berelson, B. Content Analysis in Communications Research; The Free Press: Glencoe, IL, USA, 1952.

10. Neuendorf, K.A. The Content Analysis Guidebook; Sage Publications: Thousand Oaks, CA, USA, 2002.

11. Duriau, V.J.; Reger, R.K.; Pfarrer, M.D. A content analysis of the content analysis literature in organization studies: Research themes, data sources, and methodological refinements. Organ. Res. Methods 2007, 10, 5-34.

12. Giunipero, L.C.; Hooker, R.E.; Joseph-Matthews, S.; Yoon, T.E.; Brudvig, S. A decade of scm literature: Past, present and future implications. J. Supply Chain Manag. 2008, 44, 66-86.

13. Seuring, S.; Gold, S. Conducting content-analysis based literature reviews in supply chain management. Supply Chain Manag. Int. J. 2012, 17, 544-555.

14. Hofmann, E. Supply chain finance: Some conceptual insights. In Logistik Management-Innovative Logistikkonzepte; Lasch, R., Janker, C.G., Eds.; Deutscher Universitatverlag: Wiesbaden, Germany, 2005; pp. 203-214.

15. Hu, Y.; Huang, S. Supply chain finance: Background, innovation and definition. J. Financ. Res. 2009, 8, 194-206. (In Chinese)

16. $\mathrm{Xu}, \mathrm{X}$; Xia, J. Issues on the innovative development of supply chain finance in China. Shanghai Econ. Rev. 2010, 3, 23-26. (In Chinese)

17. Chen, X.; Zhu, D. System value of 3 pl to the supply chain with capital constraints. J. Syst. Eng. 2008, 23, 666-673. (In Chinese)

18. Hofmann, E. Inventory financing in supply chains. Int. J. Phys. Distrib. Logist. Manag. 2009, 39, $716-740$.

19. He, J.; Jiang, X.; Wang, J. Analysis of stackelberg game between banks and logistics enterprise in inventory financing. Financ. Trade Res. 2012, 125-131. (In Chinese)

20. Bai, S.; Liu, H.; Tao, Y. A study of enterprise income with supply chain in financing. Econ. Manag. J. 2008, 19-20, 139-143. (In Chinese)

21. Ma, Z.; Zhu, D. Research of the logistics enterprises decision-making in the inventory financing. J. Syst. Eng. 2011, 26, 346-351. (In Chinese)

22. Xu, P.; Wang, Y.; Yang, J. Study of incentive and supervision mechanism of banks based on FTW of principal-agent mode towards TPL. J. Manag. Sci. 2008, 21, 108-114. (In Chinese)

23. Wen, Y.; Ye, Q. Analysis of the gaming between banks and enterprises under self-liquidating trade finance. Chin. Soft Sci. Mag. 2011, 54-60. (In Chinese)

24. Johnson, M.; Hofmann, E. Financial Issues in Supply Chain Management and Supply Chain Finance. Available online: http://www.emeraldgrouppublishing.com/products/journals/call_for_ papers.htm?id=4933\&PHPSESSID=tke8d6c0efueo0lv3pm3rbkdl0 (accessed on 16 March 2014).

25. Bandaly, D.; Satir, A.; Kahyaoglu, Y.; Shanker, L. Supply chain risk management-I: Conceptualization, framework and planning process. Risk Manag. (BAS) 2012, 14, 249-271. 
26. Harland, C.; Brenchley, R.; Walker, H. Risk in supply networks. J. Purch. Supply Manag. 2003, 9, 51-62.

27. Tang, C.S. Perspectives in supply chain risk management. Int. J. Prod. Econ. 2006, 103, 451-488.

28. Li, Y. Risk control of contract design of inventory financing under logistics financial innovation: Case of pledge-monitoring practice of express post and logistics corporation in Jiangxi. East China Econ. Manag. 2011, 26, 141-144. (In Chinese)

29. Lv, Y. The study on operation model and risk prevention of logistics enterprises in financing logistics east china. Econ. Manag. 2012, 124, 101-103. (In Chinese)

30. Chen, B.; Feng, G.; Li, Y. The value risk measurement of inventory financing. Syst. Eng. 2007, 25, 21-26 (In Chinese)

31. Bai, S. A fuzzy comprehensive evaluation of the credit level of enterprises with supply chain financing. Econ. Surv. 2011, 108-112. (In Chinese)

32. Han, G.; Li, S. Liquidity risk control of inventory financing under dynamic pledge model. Syst. Eng. 2010, 28, 18-22. (In Chinese)

33. Bai, S. An investigation of supply chain finance model based on intellectual property as collateral. Inq. Econ. Issues 2010, 67-71. (In Chinese)

34. Xiong, X.; Ma, J.; Zhao, W.; Wang, X.; Xiao, Y.; Zhang, J. Credit risk analysis of supply chain finance. Nankai Bus. Rev. 2009, 12, 92-98. (In Chinese)

35. Chang, W.; Hu, H.; Zhang, D.; Chen, B. Liquidity risk measurement of inventory financing. Forecasting 2009, 28, 71-75. (In Chinese)

36. Wu, J. The law conflict and suggestions of minor enterprise financing based chattel hypothec. Forecasting 2011, 3, 30-52. (In Chinese)

37. Lacroix, R.; Varangis, P. Using warehouse receipts in developing and transition economies. Financ. Dev. 1996, 33, 36-39.

38. Xu, X.; Deng, C.; Peng, H. Ordering strategy research based on financial supply chain under conditions of stochastic demands. Chin. J. Manag. Sci. 2011, 19, 63-70. (In Chinese)

39. Wang, Y.; Xu, P. The incentive mechanism of banks to $3 \mathrm{pl}$ considering the factor of justice preference based on FTW of principal-agent model. J. Ind. Eng./Eng. Manag. 2010, 24, 95-100. (In Chinese)

40. Zhao, D.; Liu, J. Research on pricing method of tpl financing monitoring service in the FTW pattern. Soft Sci. 2011, 25, 111-114. (In Chinese)

41. He, J.; Wang, J.; Jiang, X. The price risk decision of inventory portfolio in supply chain finance. Manag. Rev. 2013, 25, 163-176. (In Chinese)

42. Hu, H.; Xue, M.; Zhang, L. Study on the influence of supply chain partnership on SMEs' working capital. Econ. Manag. J. 2014, 38, 54-65.

43. Zsidisin, G.A.; Jun, M.; Adams, L.L. The relationship between information technology and service quality in the dual-direction supply chain. Int. J. Serv. Ind. Manag. 2000, 11, 312-328.

44. Stevens, G.C. Integrating the supply chain. Int. J. Phys. Distrib. Mater. Manag. 1989, 19, 3-8.

45. Moshkdanian, F.; Molahosseini, A. Impact of supply chain integration on the performance of bahman group. Interdiscip. J. Contemp. Res. Bus. 2013, 5, 184-192.

46. Mentzer, J.T.; DeWitt, W.; Keebler, J.S.; Min, S.; Nix, N.W.; Smith, C.D.; Zacharia, Z.G. Defining supply chain management. J. Bus. Logist. 2001, 22, 1-25. 
47. Randall, W.S.; Farris, M.T., II. Supply chain financing: Using cash-to-cash variables to strengthen the supply chain. Int. J. Phys. Distrib. Logist. Manag. 2009, 39, 669-689.

48. Mentzer, J.T.; Konrad, B.P. An efficiency/effectiveness approach to logistics performance analysis. J. Bus. Logist. 1991, 12, 33.

49. Caplice, C.; Sheffi, Y. A review and evaluation of logistics metrics. Int. J. Logist. Manag. 1994, 5, $11-28$.

50. Caplice, C.; Sheffi, Y. A review and evaluation of logistics performance measurement systems. Int. J. Logist. Manag. 1995, 6, 61-74.

51. Gunasekaran, A.; Patel, C.; McGaughey, R.E. A framework for supply chain performance measurement. Int. J. Prod. Econ. 2004, 87, 333-347.

52. Lai, K.; Ngai, E.W.T.; Cheng, T.C.E. Measures for evaluating supply chain performance in transport logistics. Transp. Res. Part E: Logist. Transp. Rev. 2002, 38, 439-456.

53. Biederman, D. Logistics financiers. J. Commer. 2004, 5, 40-41.

54. Chen, X.; Cai, G. Joint logistics and financial services by a 3pl firm. Eur. J. Oper. Res. 2011, 214, 579-587.

55. Brandt, L.; Li, H. Bank discrimination in transition economies: Ideology, information, or incentives? J. Comp. Econ. 2003, 31, 387-413.

56. Liu, Q.; Tian, G.; Wang, X. The effect of ownership structure on leverage decision: New evidence from Chinese listed firms. J. Asia Pac. Econ. 2011, 16, 254-276.

57. Child, J. Context, comparison, and methodology in Chinese management research. Manag. Organ. Rev. 2009, 5, 57-73.

58. Avittathura, B.; Swamidass, P. Matching plant flexibility and supplier flexibility: Lessons from small suppliers of U.S. Manufacturing plants in India. J. Oper. Manag. 2007, 25, 717-735.

59. Yaibuathet, K.; Enkawa, T.; Suzuki, S. Influences of institutional environment toward the development of supply chain management. Int. J. Prod. Econ. 2008, 115, 262-271.

60. Qing, Y.; Cong, L. The barriers analysis for the implementation of SCM of Chinese firms. Enterp. Manag. 2004, 6, 112-114.

61. Huo, B.; Han, Z.; Zhao, X.; Zhou, H.; Wood, C.H.; Zhai, X. The impact of institutional pressures on supplier integration and financial performance: Evidence from China. Int. J. Prod. Econ. 2013, 146, 82-94.

62. Su, Q.; Shi, J.; Lai, S. Study on supply chain management of Chinese firms from the institutional view. Int. J. Prod. Econ. 2008, 115, 362-373.

63. Pasmore, W.A.; Stymne, B.; Shani, A.B.; Mohrman, S.A.; Adler, N. The promise of collaborative management research. In Handbook of Collaborative Management Research; Shani, A.B., Adler, N., Mohrman, S.A., Pasmore, W.A., Stymne, B., Eds.; Sage: Thousand Oaks, CA, USA, 2007.

64. Wuttke, D.A.; Blome, C.; Foerstl, K.; Henke, M. Managing the innovation adoption of supply chain finance-Empirical evidence from six European case studies. J. Bus. Logist. 2013, 34, 148-166.

65. Eisenhardt, K.M. Building theories from case study research. Acad. Manag. Rev. 1989, 14, 532-550.

66. Manuj, I.; Sahin, F. A model of supply chain and supply chain decision-making complexity. Int. J. Phys. Distrib. Logist. Manag. 2011, 41, 511-549. 
67. Jiang, B.; Frazier, G.V.; Heiser, D. China-related pom research: A literature review and suggestions for future research. Int. J. Oper. Prod. Manag. 2007, 27, 662-684.

68. Liu, X. China-based logistics research: A review of the literature and implications. Int. J. Phys. Distrib. Logist. Manag. 2014, 44, 392-411.

69. Zhao, X.; Flynn, B.B.; Roth, A.V. Decision sciences research in China: A critical review and research agenda—Foundations and overview. Decis. Sci. 2006, 37, 451-496.

70. Tsui, A.S. Editor's introduction-Autonomy of inquiry: Shaping the future of emerging scientific communities. Manag. Organ. Rev. 2009, 5, 1-14.

(C) 2015 by the authors; licensee MDPI, Basel, Switzerland. This article is an open access article distributed under the terms and conditions of the Creative Commons Attribution license (http://creativecommons.org/licenses/by/4.0/). 